\title{
Neo-Statecraft Theory, Historical Institutionalism and Institutional Change
}

Toby S. James

University of East Anglia

www.tobysjames.com

t.s.james@uea.ac.uk

\begin{abstract}
This article provides a critical examination of the contribution that statecraft theory, which has been subject to recent revision and development, makes to the literature on institutional change. It articulates an emergent neo-statecraft approach that offers an agent-led form of historical institutionalism. This overcomes the common criticism that historical institutionalists underplay the creative role of actors. The article also argues that the approach brings back into focus the imperatives of electoral politics as a source of institutional change and provides a macro theory of change which is also commonly missing from historical institutionalist work. It can therefore identify previously unnoticed sources of stability and change, especially in states with strong executives and top-down political cultures.
\end{abstract}

This paper is a pre-print of the following published article:

James, T.S. (forthcoming) 'Neo-Statecraft Theory, Historical Institutionalism and Institutional Change', Government and Opposition. 
Statecraft theory, originally developed by Jim Bulpitt, has traditionally been considered to be outside the mainstream of British, let alone comparative, political science. However, the approach is now gaining critical acclaim. Bulpitt's article in Political Studies (1986a) was recently amongst the twelve 'top voted' articles published in the journal between 1953 and 2010. David Marsh (2012: 48-9) has recently argued that the statecraft approach is a key alternative organising perspective to understanding British governance. Moreover the approach has been applied to new problems and has been developed by a second wave of scholarship. Yet many, especially outside the study of British politics, remain unfamiliar with the statecraft approach, and its contribution to key contemporary debates in political science has not been assessed.

This article considers the 'added value' that statecraft theory may have for contemporary theories of institutional change. Explaining institutional change remains a central puzzle for new institutionalists. Since March and Olsen's (1984) claim that institutions matter, a huge variety of institutionalisms have proliferated (Hall and Taylor 1996; Lowndes 1996; Lowndes and Roberts 2013; Peters 1999). However, explaining both continuity and change remains a central challenge (Hall 2010: 204). Bulpitt's earlier work on territorial relations has been framed as a historical institutionalist approach (Bradbury 2006, 2010), but there has been no similar analysis of the statecraft approach, which crystallized much of this thinking about politics or the way in which the statecraft approach has evolved by recent scholarship. It is noteworthy that in Lowndes and Roberts' recent book Why Institutions Matter (2013), Bulpitt and statecraft receive no mention.

This article distils a neo-statecraft framework based on the more recent scholarship and argues that it makes three distinctive contributions to the existing literature on institutional change. First, it offers an agent-led form of historical institutionalism which overcomes the common criticism that historical institutionalists underplay the creative role of actors. Second, the approach brings back into focus the imperatives of electoral politics as a source of institutional change which is commonly missing from historical institutionalist work. Third, it provides a macro theory of change. Neo-statecraft theory can therefore identify previously unnoticed sources of stability and change, especially in states with strong executives and top-down political cultures.

The article begins by sketching out the neo-statecraft approach before reviewing historical institutionalist accounts of change and the criticisms levelled against it. The case for the contribution of the statecraft approach is then made. 


\section{FROM STATECRAFT TO NEO-STATECRAFT}

The study of political elites and leaders is one of the cornerstones of political science and of central importance to any society. Statecraft is a framework for studying this terrain which was first developed by British academic Jim Bulpitt in his 1986 Political Studies article on the Thatcher administration's approach to economic policy. Jim Bulpitt's earlier work (1967) focused on parties in local politics, and territorial relations in Territory and Power (Bulpitt [1983]2008). However, it was his statecraft approach which crystallized his ideas on government and governance. He later used it to understand a range of other issues, such as the relationship between local and central government (Bulpitt 1989), race relations (Bulpitt 1986b), foreign policy and Europe (Bulpitt 1988). Economic policy retained a central focus (Bulpitt and Burnham 1999).

The statecraft approach is concerned with how political elites confront and respond to governing challenges. Analytical primacy is given to the court which 'will include the formal Chief Executive plus his/her political friends and advisors' (Bulpitt 1995: 518), who are assumed to be self-interested, rational and cohesive actors. The court's primary concern is to achieve successful statecraft; the 'art of winning elections and achieving some necessary degree of governing competence in office' (Bulpitt 1986a: 21). It does not therefore (necessarily) try to govern in the national interest, or on the basis of ideological views. What matters is winning, and winning again. It will seek to achieve this through the use of 'governing codes' which are a 'set of relatively coherent principles or rules underlying policies and policy related behaviour' (Bulpitt 1996: 1097) and 'a set of political support mechanisms designed to protect and promote the code and objectives' (Bulpitt 1996: 1097). The original support mechanisms were party management, a winning electoral strategy, political argument hegemony and, most importantly, governing competence (Bulpitt 1986a: 22). Courts operated within a structural context which affected their ability to achieve successful statecraft (Bulpitt 1988: 185).

The approach has been subject to criticism. Rhodes has claimed there is no counterfactual to the approach (Rhodes 1988: 33). Bulpitt ([1983]2008: 239) accepted that 'the thesis [is] untestable, [it] cannot be disproved'. Bulpitt was criticized too for being 'no system builder'. Much of his later work was unpublished and on some points contradictory (Rhodes and Tiernan 2013). It has also been suggested that many of the concepts used were vague and ill-defined, making them unusable for empirical research (Evans 2006: 53). Finally, the approach has been criticized for being reductionist (Marsh 1995). Social and political change is multi-causal but statecraft is an account of change which is organized by and around the interests of one actor. 
However, a second wave of scholarship has taken statecraft theory beyond its original formulation. The contours of a neo-statecraft approach are now clear. Firstly, there has been a concern to establish the epistemological and ontological position of the approach. Buller (1999: 691) argued that it was a neglect of these issues that left the approach open to the criticism of being 'reductionist and insensitive to empirical criticism'. He anchored the approach within the realism of Andrew Sayer (1992). Meanwhile, James (2012: 76-9) uses critical realism. This position assumes that there are separate domains of reality and that not all social phenomena and relationships, including elite activity, are directly observable. The observable should often be considered as the 'effects of these (unobservable) causal mechanisms' (Savigny 2007: 37). Positivist falsification based on observation is therefore not an appropriate strategy for testing the approach.

Secondly, some of the contradictory ideas and concepts have been teased out and replaced to enable 'system building'. Buller and James (2014), for example, have undertaken work on the issue of structure and agency by criticizing Bulpitt's concept of the natural rate of governability and replaced it with the concept of a structural context.

Thirdly, there has been a move to consider how some of Bulpitt's concepts, such as governing competence and party management, can be operationalized using research from comparative party politics (Buller and James 2012). These have been applied to help assess political leaders (also see Buller and James 2012; Stacey 2013).

Fourthly, the concepts from the approach have been argued to be useful for understanding politics across time and space and at different levels of governance. James (2012) uses the approach to understand the reform of election administration in the US, UK and Ireland. Stacey (2013) has made the case for using the approach to assess French political leaders. McKenna (2012) argues that Bulpitt's statecraft concepts can be applied to local government. Savitch and Osgood (2010) used Bulpitt's earlier work on territorial relations to understand urban policy in the US. The approach is no longer necessarily focused on British politics. Instead, it focuses on identifying regularities and trajectories in elite governance across time and space.

Lastly, the approach has been developed explicitly to explain institutional change. Bulpitt was clearly concerned with constitutional management in the British polity in his earlier book, Territory and Power ([1983]2008). However, the importance of constitutional management was not explicitly embedded in the core support mechanisms of the statecraft approach. James (2012) thus argues that there should be a fifth support mechanism to statecraft theory: bending the rules 
of the game. From this perspective, institutions are considered to be formal, legal-political rules that can be enforced by third parties rather than informal 'anthropological' ones. ${ }^{1}$

Neo-statecraft theory therefore responds significantly to the criticisms that have been levelled at it to date and lays the path for significant system building. However, there has been no assessment of the contribution that this approach makes to the analysis of the causes of institutional change and continuity, which is a central question in political science. Analysis has so far focused on Bulpitt's earlier text, Territory and Power, with Bradbury $(2006,2010)$ arguing that the approach was historical institutionalist. For Bradbury (2010: 320), Territory and Power 'was the more difficult mother work to which "The Thatcher Statecraft" was the later offspring'. Territory and Power, Bradbury argues (2006: 559), was a 'realist historical institutionalist account of UK territorial politics' which should be seen as part of 'the intellectual turn since the 1980s towards temporal analysis of political development' (Bradbury 2010: 318). Bulpitt's work on territorial relations, argues Bradbury (2010: 318), stressed a need to understand political development in a long-term context, a concern that temporal political science should try to 'periodize modern and contemporary history better' (Bradbury 2010: 339) and a discomfort with historians and political scientists laying claim to predictive knowledge - all key aspects of historical institutionalism. Moreover, Bulpitt built explanations of change in territorial relations on many of the concepts and terms commonly used by historical institutionalists to explain change, such as path dependency, positive feedback mechanisms and critical junctures (Bradbury 2010: 335-6). Clearly, Bulpitt's original statecraft approach might have emerged from his earlier work. However, there is a need to consider the contribution of the more recent framework. To do this, a review of historical institutionalism and the problems that it faces in explaining change is required.

\section{THE FAILURES OF HISTORICAL INSTITUTIONALISM}

The central assumptions of historical institutionalism, ${ }^{2}$ writes Elizabeth Sanders (2006: 39), are that: 'human political interactions should be studied (a) in the context of rule structures that are themselves human creations; and (b) sequentially ... rather than to take a snapshot if those interactions at only point in time, and in isolation from the rule structures (institutions) in which they occur'. Historical institutionalists distinguish themselves from rational choice institutionalists by emphasizing how the motives and actions of actors depend on the social-historical institutional setting (Adcock et al. 2007: 280). They distinguished 
themselves from sociological institutionalists by having concerns about power at the forefront of the analysis.

Institutional development is typically characterized as being prone to long periods of stability punctuated by rare and brief periods of instability in which change is possible, but not inevitable (Capoccia and Keleman 2007: 341). The long periods of stability are explained through the concept of path dependencies. Mahoney $(2000: 507,510)$ defines these as 'causal processes that are highly sensitive to events that take place in the early stages of an overall historical sequence'. Early historical events influence, but do not completely determine, future outcomes. There remains a role for contingency over a series of events and relative uncertainty. He identifies two different types of dependencies. The first are self-reinforcing sequences, in which 'initial steps in a particular direction influence further movement in the same direction such that over time it becomes difficult or impossible to reverse direction' (Mahoney 2000: 512). Path-dependencies are therefore mechanisms whereby institutional reproduction is ensured or 'locked in' over time. Mahoney's second dependency type are reactive sequences, which are 'chains of temporarily ordered and causally connected events' (Mahoney 2000: 526). One event can set in motion a sequence of events and therefore influence institutional development.

Path dependencies are thought to be usually so strong that change can only occur during critical junctures. Capoccia and Kelemen (2007: 343) define these as: "A situation in which the structural (that is, economic, cultural, ideological and organizational) influences on political action are significantly relaxed for a relatively short period with two main consequences: the range of plausible choices open to powerful political actors expands substantially and the consequences of their decisions for the outcome of interest are potentially much more momentous'. These moments are often described through metaphor. Krasner $(1984,1988)$ invokes a metaphor of the changes to an animal species, which might occur due to external shocks such as climate change or environmental disaster. Elsewhere, they referred to as times of 'punctuated equilibrium' (Baumgartner and Jones, 1991). On these occasions path-dependencies can be broken by the 'contingent' actions of actors or events and change can, but won't necessarily, occur.

\section{An Explanation of Continuity not Change?}

The traditional criticism of the historical institutionalist literature is that its explanation of change is not satisfactory. Peters et al. (2005: 954-5) suggest that there is no theory of change because 
the aim is to explain continuity. The concepts of critical junctures and punctuated equilibrium make the sources of change exogenous to the model and do not help identify what they might be; they 'fall outside of the existing scientific theory' (Mahoney, 2000: 514). As Steinmo et al. (1992: 15) famously commented: 'institutions explain everything until they explain nothing. Institutions are an independent variable and explain political outcomes in periods of stability, but when they break down, they become the dependent variable... the logic of the argument is reversed from "institutions shape politics" to "Politics shape institutions".' Historical institutionalist theories therefore appear weak at explaining how and why macro phenomena penetrate meso and micro levels (also see: Mahoney and Thelan 2010: 6-7).

More recent work on institutions has developed partially with this criticism in mind. A range of studies in a collection edited by Streek and Thelan (2005) explain how transformative change can result from the accumulation of gradual and incremental changes which create tipping points' for more dramatic change. They argue that change can therefore be endogenous to institutions as it results from "inherent ambiguities and "gaps" that exist by design or emerge over time between formal institutions and their actual implementation or enforcement' (Streek and Thelan 2005: 19). They develop five modes of institutional change: displacement, layering, drift, conversion and exhaustion. ${ }^{3}$ These are both a descriptive typology of the ways in which institutions might change and a way of explaining institutional change. The concept of drift, for example, explains how institutions require 'active maintenance; to remain what they are, how they need to be reset and refocused, or sometimes more fundamentally recalibrated or renegotiated, in response to changes in the political and economic environment in which they are embedded' (Streek and Thelan 2005: 24). In short, institutions themselves can be a force of institutional change because they are dynamic entities. The criticism that too much remains exogenous has therefore been partially answered but still has resonance.

\section{Structure and Agency}

A second concern commonly raised about historical institutionalism is its position on structure and agency. Historical institutionalists are accused of giving institutions too much power over individuals: they demonstrate how the institutional setting in which individuals live influences their behaviour but how can individuals shape institutions? According to Peters (1999:71): 'There appears to be an implicit assumption of the approach that when individuals choose to participate 
in an institution they will accept the constraints imposed by that institution, but that linkage is not explored directly by scholars working in the tradition'.Instead, as Mahoney (2000: 514) notes, 'the specific choices and "agency" of particular individuals' tend to be listed among those factors which are 'contingent' and are therefore given less theoretical or empirical examination themselves. For Hay and Wincott (1998: 957): 'historical institutionalism . . . offers great potential. Whether that potential will be realized, however, depends ultimately on the willingness of institutionalists ... to pose again the fundamental and difficult question of the relationship between agents and structures, between institutional architects, institutionalised subjects and institutional environments'.

More recent institutional theory notes that agency can be important at particularly contingent moments. Ira Katznelson (2003), for example, argues that institutional path dependencies are central during 'settled' times but agency becomes important during 'unsettled' times. All four of the modes of institutional change identified by Mahoney and Thelan (2010) involve an agent of one form or another. However, while there are elements of agency in some of the work considered to be historical institutionalist, it is worth remembering that the historical institutionalism paradigm was self-consciously constructed to make the point that change is not easy and that human agency matters less than we normally think. It therefore retains the claim that only in exceptional circumstances do agents trump institutions (also see Mendez 2012: 154$6)$.

However, might Katznelson's 'unsettled times' be a more general condition than originally thought? In many contexts there might be powerful agents who can readily break institutional path dependencies. In some contexts, might agency be more important than structure? Examining when, where and how crucial agents seek to break path-dependencies can therefore make a crucial contribution to understanding institutional development. In the context of majoritarian democracy with top-down political cultures, this article argues, statecraft is important.

Statecraft as historical institutionalism

This brief review of historical institutionalism allows the contribution of neo-statecraft theory to be identified. Neo-statecraft theory fits with historical institutionalism in four overlapping ways. Firstly, the statecraft approach continued Bulpitt's concerns with historical context and temporal 
development present in Territory and Power. Bulpitt became increasingly vocal about the need for a historical understanding of politics because of his dissatisfaction with the state of the academic disciplines of British political science and history and their interrelationship. According to Bulpitt, these two academic subjects shared (or should share) empirical material and analytical analysis but in short did not 'speak' to one another. Bulpitt (1995: 510) was concerned that political science: 'now has a less systematic and continuous interest in the past than sociology, economics, and, even, geography. Contemporary political science is confined to a laager called "the present", which is increasingly and profitably penetrated by these rival disciplines.' For him, 'the 1190s are as interesting and as important as the 1990s' (Bulpitt 1996: 1094). Political science had developed a disease of 'presentism' by limiting the basis of empirical research. The result was the importing of 'rented histories', where political scientists borrowed accounts of the past from historians to contextualize their own research of the present. This left political scientists reliant on other disciplines' and researchers' analysis and assumptions. One example that Bulpitt (1996) cites is the 'post-war consensus', which he empirically disputes, but which formed the basis of much subsequent analysis of Thatcherism and New Labour in the UK. Bulpitt $(1995,1996)$ therefore tried 'to reformulate ... [political science's] connection with the past'. He argued that 'political science would benefit from another attempt to reformalise its connections with past politics' in the form of analysis of historical politics (Bulpitt 1995: 510). Two of the most recent applications of statecraft theory have sought to understand change in a historical perspective. James (2012) studies how partisan interest in changing certain electoral rules varies over time from the franchise becoming widespread to the present day. Buller's analysis (2000) of the court's position towards the European Union is situated into the historical development of post-war British politics.

Secondly, the use of concepts such as critical junctures continued. Bulpitt periodized twentieth-century British politics into statecraft regimes. However, the effectiveness of these regimes was undermined by exogenous developments. The birth of electoral democracy, for example, forced professional elite politicians into a major reconsideration of statecraft strategy because it gave rise to demands for responsibility for macro-economic policy in a context of a profoundly uncompetitive economy, and a weak external security position (Bulpitt 1996: 1098103). Subsequent critical junctures identified by Bulpitt (1988: 188-91) included the emergence of an open polity in the 1980s. 
A third important convergence between neo-statecraft and historical institutionalism is the theory of actor motivation explicit in the statecraft approach. For Bulpitt, the court is a rational, self-interested actor. The assumptions of self-interest and rationality have strong connotations in political science because they are the core assumptions of rational choice theory. But the statecraft approach should not be misinterpreted as a rational choice approach. Bulpitt claims that those assumptions of politicians are justified because of the particular institutional and historical context in which elites find themselves in Britain. A single member plurality electoral system at Westminster, an adversarial party system, the professionalization of politics and lack of institutional pluralism (prior to Welsh and Scottish devolution) combine to ensure that British politicians are constantly concerned with winning national elections above all else. Bulpitt (1996: 225) therefore argues that: 'In combination, these structural characteristics of modern British politics have produced party elites with common, initial, subsistence-level objectives, namely winning national office, avoiding too many problems while there and getting re-elected'. It is therefore the historical and institutional context of British politics that makes party leaders desperate to win elections because the consequences of defeat . . . are so awful' (Bulpitt 1988: 188). This is significant because it fits closely with the historical institutionalist claim - in contrast to rational choice institutionalism - that the motives and actions of actors are dependent on a particular institutional setting (Adcock et al. 2007: 280). In contrast, rational choice theory takes preferences and motives as external and fixed.

Fourthly, the neo-statecraft approach fits with historical institutionalism because it shares concerns about identifying context-dependent regularities in the world. If the approach is premised in realism then neo-statecraft shares realism's aim of identifying regularities which are causal mechanisms, whose effects vary according to context rather than scientific laws that enable prediction (Sayer 2000: 14). This is also a core concern of those seeking to establish path dependencies or reactive sequences (Mahoney 2000; Mahoney and Rueschemeyer 2003). Bulpitt's frequent reference to political historians such as Maurice Cowling $(1967,1971)$ has caused some consideration as to whether Bulpitt's work fits better within Tory historiography. Mark Bevir (2010: 445-6) notes that it is from his reading of eighteenth-century British history that Bulpitt draws his concepts of 'low' and 'high' politics, and local and central elites. Bulpitt's work also overlaps with Cowling's focus on elite politicians who were considered as being motivated by ambition over principle (Craig 2010). However, Bulpitt (1996: 1093) was critical of the a-theoretical approach that historians often took which paid 'little attention to political 
science concepts and "theory"'. He therefore sought a theoretical framework with abstract assumptions. Moreover, the second wave of statecraft scholarship has explicitly used the approach as a framework for establishing regularities. James (2012) uses it as a framework for identifying the causes of reform of electoral institutions in a comparative perspective. Mckenna (2012) uses his local model to understand regularities in local elite behaviour towards participatory initiatives. The second wave of literature therefore consolidates Bulpitt's differences with Cowling, who was not interested in developing such theoretical extrapolations. Cowling (1980: 258) thought that history 'knew nothing and cared less about a "natural or logical development" and had nothing to learn from "cause and effect". Craig (2010: 465-75) argues that Cowling's writing therefore fitted well with the work of R.G. Collingwood and Michael Oakeshott. The same cannot be said of Bulpitt. Bevir (2010) therefore concluded that Bulpitt was too fixed on 'modernist empirical topics' to be an interpretative historiographical approach. </bi>

\section{BEYOND HISTORICAL INSTITUTIONALISM: THE ROLE OF AGENCY IN CHANGE AND CONTINUITY}

Neo-statecraft theory does naturally appear to be part of the family of historical institutionalist approaches. It is also distinct from it. Why? As noted above, according to Peters et al. (2005: 1284), historical institutionalism 'lacks any clearly identified source of agency'. For Mahoney, agency is often an unexplained 'contingency'. However, the importance of agency is clearly present in neo-statecraft theory. What evidence is there of this?

First, throughout Bulpitt's Territory and Power ([1983]2008) and his statecraft work the principal agent is attributed a degree of strategic reflexivity. It is able to make strategic choices even if these are affected by the structural context in which the court finds itself. Even in his earlier work, Bulpitt describes a range of approaches that the centre might take towards territorial relations. A coercive power model could be enforced through the use of threats and coercion. A central autonomy model could be established in which the centre seeks cooperation and acquiescence from the periphery. Lastly, a capital city bargaining model sees the periphery 'on top'. Bulpitt suggested that the central autonomy model was more likely to be successful in the UK context. The choice of approaches towards centre-periphery relations is also heavily influenced by existing power relations and resources and past historical legacies (Bulpitt [1983]2008: 67-9). However, the centre does have a degree of contextual choice of strategy. Similarly, he writes that the statecraft that Conservative leaders developed after the mid-1880s 
was based on their perceptions of developments such as the rise of popular government and the Labour Party (Bulpitt 1986a: 27). While he stressed that some statecraft strategies were rejected because of their weaknesses, he was clear that there is contingency because of leadership agency. Monetarism might have been the only option for the Thatcher administration to achieve successful statecraft, in his opinion (Bulpitt 1986a: 33), but it was not inevitable that it would accept it because Conservative leaders had made past errors. He singled out Edward Heath as a 'total failure on all dimensions' (Bulpitt 1986a: 30).

Second, in Territory and Power, change is explained through historical institutionalist concepts such as critical junctures, as Bradbury noted, but also the strategic activity of the court. For example, Bulpitt claims that the 'old order' of territorial relations was challenged during the period 1870-1926. This was because of a number of developments such as the collapse of an external support system, social change, the rise of popular government and demands for a new territorial constitution. However, the agency of the centre was also vital in determining how these broader developments affected territorial relations. The centre was strategically 'reacting to some of these challenges, ignoring others and trying to construct or reconstruct a viable system of territorial management in an awkward world' (Bulpitt [1983] 2008: 112). Salisbury is attributed a crucial role. For Bulpitt: 'Salisbury's general strategy was to delay and weaken the forces of "aggressive democracy"' ([1983] 2008: 114). His 'importance [was] that he decided to pursue the code with renewed vigour in the latter part of the nineteenth century' (Bulpitt [1983] 2008: 115). Meanwhile in the construction of l'ancien régime, Bulpitt ([1983] 2008: 136) claims that the court was posited with favourable circumstances in which it could 'take advantage of this politically weak periphery to construct a regime more centralised than in the past'. It eventually 'passively accepted' a system 'handed to it on a plate' (Bulpitt [1983] 2008: 138). Individual errors and actions also affect political development. For example, 'Mr Heath's "Declaration of Perth" in May 1968 gave a vague commitment to an elected Scottish Assembly without consulting the party in England'. This was as important in the decline of the dual polity as any other factor (Bulpitt [1983] 2008: 149-50).

Third, in later devising the statecraft approach, Bulpitt gave agency more explicit recognition in the model's assumptions. A core assumption was that elites were rational, selfinterested agents. This attributes them with a degree of reflexivity in their decision-making process. Importantly, agents were not conceived as having full knowledge. They therefore only choose from a limited menu of strategies which are determined by historical, cultural and 
ideational context. But while these constraints do remain, they are still reflective and purposive agents.

In summary, the centre continually finds itself in a strategically selective environment in which some choices are more feasible than others. However, the court still retains a degree of strategic choice and the decisions made reconfigure and reconstruct future institutional developments. This degree of agency in Bulpitt's work goes someway beyond that given to it by historical institutionalists and responds to Peters et al.'s call for a theory of agency to be incorporated into the approach. The revised statecraft approach therefore represents an agencyled approach to continuity and change within historical institutionalism. This stream can be distinguished from structure-led approaches implicit in the original work of Pierson and others.

\section{BRINGING ELECTORAL POLITICS BACK IN}

One advantage of the statecraft approach is that it brings the imperatives of electoral politics back into the analysis of institutional change and stability and allows public administration and executive politics to be reconnected. According to Peters et al. (2005: 1283): 'most scholars working in [the historical institutionalist] ... approach, especially those focusing upon the state, overemphasize the importance of civil servants and bureaucrats in policymaking processes, belittling excessively the continuing (and on occasions elemental) significance of politicians as creative actors'.

The role of politicians as creative actors in policy change has often been neglected as part of the growth of public administration as a sub-discipline. According to Lodge and Wegrich (2012: 213): 'the study of public administration seems to have lost its focus on one of its key aspects, namely the contribution of politics (if not 'power') to the design and practice of administrative arrangements.' Lodge and Wegrich (2012: 219) explain that the result has been that public administration has explored a range of research questions relating to public management reform and policy change but has not grasped the importance of political context. As a result, public management reform has therefore been discussed without sufficient consideration of why reforms were adopted at some points by politicians, but not others (Lodge and Wegrich 2012: 218-19); the development of performance management and regulatory regimes has been analysed without consideration of why politicians would want such regimes that might 'illustrate their lack of progress' (Lodge and Wegrich 2012: 219-20); and the move towards governance and the hollowing out of the state has been described without pointing to its 'inherently political 
nature' (Lodge and Wegrich 2012: 220). They therefore make the case for the study of executive politics, which 'is about the systematic study of the political factor within administrative or bureaucratic arrangements, and about the administrative factor in political life' (Lodge and Wegrich 2012: 214).

The statecraft approach is one framework of executive politics which brings politics to the fore and helps to explain a range of sources of policy change by reconnecting public administration with the study of comparative politics and electoral behaviour. It opens up a wider and untapped agenda to note how the strategic manoeuvring of the court can affect policy development by connecting with electoral studies and comparative politics. The court's strategic attempts to achieve its support mechanisms can bring about policy change. The need to develop a winning electoral strategy may mean that they will, for example, quicken, slow or cancel policy change to fit with the electoral cycle. Blais and Nadeau (1992), for example, argue that politicians will tend to implement their most popular policies immediately before an election and their most unpopular immediately after. Likewise, courts may often seek to redress unfavourable polls with short-term electorate pleasers such as 'budget give-aways', they may undertake policy reversals if they appear to be unpopular or strategically respond to the policies of the opposition. The need to develop a perception of governing competence may explain why the court depoliticizes decisions by 'tying one's hands' and putting policy control beyond their immediate control (Burnham 2001; Flinders and Buller 2006). The need for effective party management may mean that policy will change as a court needs to placate particular wings of its party. The uneven playingfield of party politics can also affect policy. Some parties, such as business parties, can be disproportionately under- or over-funded (Hopkin and Paolucci 1999), which means that certain policy outcomes are more likely. Courts might also engage in collaborative strategies to make successful statecraft more likely, such as party cartelization (Katz and Mair 2009). This cartelization will prevent some issues entering the policy agenda or being legislated on. There is also empirical evidence that policy is shaped by the executive's expected political return. Bertelli and John (2013) undertake a time series analysis of data from the 'Speech from the Throne' in the UK to show how governments prioritize policy areas in which they expect electoral return to be maximized.

Is Bulpitt's principal actor designation is still justifiable for researching governance in the advancing twenty-first century? Specifying the court as the central actor may be criticized from the perspective that power is fluid in democratic polities such as Britain. Furthermore, a number 
of fundamental changes have been claimed to have taken place in policy-making in developed capitalist democracies which have undermined the capacity of the central state and its managers. Firstly, it is argued that the imperatives of globalization have affected its ability to exercise direction over policy, particularly over the economy and welfare (Ohmae 1990; Strange 1996). Secondly, governance has become more multilayered between local, national, regional and European levels (Brenner 2004). Thirdly, the development of information and communications technology (ICT) systems brought about a rapid flow of cross-border information which made power more dispersed and fragmented (Castells 1996). Fourthly, the introduction of new public management reforms has been said to reduce the governing capacity of the central state. The privatization and contracting-out of public services, coupled with a proliferation of QUANGOs has increased the number of policy actors involved in making decisions. There has therefore been a perceived need for 'joined-up government' (Davies 2009). These collective changes have been said to have brought about the 'new governance' where central national executives have become less active in the making of decisions over public policy (Rhodes 1997). Britain, the subject of Bulpitt's analysis, has therefore been described as a differentiated polity. Focusing on the court may seem to be an outdated approach.

That said, there are several reasons why a centre-approach might be useful. First, the national state is not necessarily in demise, so its focus remains important. There is a countervailing literature to the hypoglobalist school of thought that makes the case that the importance of globalization on national policy discretion is often exaggerated, at least in some states. Central government managers have often been the 'midwives' of internationalization (Hirst and Thompson 1999; Weiss 1998). Second, recent literature on networks questions the pluralistic nature of contemporary governance that is often portrayed. Greenaway et al. (2007) suggest that policy-making through networks is not as democratic as its proponents suggest. Their case of private finance initiative (PFI) projects under New Labour revealed how 'powerful actors, or policy entrepreneurs, with their own agenda, still have the facility, by exercising power and authority, to shape and determine the policy outputs through implementation networks' (Greenaway et al. 2007: 717) A significant degree of central government power and local elite domination were present, they suggested. Marsh $(2008)$ and Davies $(2009,2011)$ also separately question the fluidity of power in networks. Policy network theory implies that there is cooperation and trust between actors. However, networks often have asymmetric power relations and look more like hierarchies. 
Moreover, Bulpitt did not always see the centre as necessarily being particularly strong, or at least, this assumption was not pivotal to his model. His approach to territorial politics was built on the criticism that many previous approaches saw the centre as having power that it did not necessarily have. The centre was frequently considered to be in a weak position. This was why it was less likely to be able to control the periphery and allowed it considerable discretion over policy issues.

A more significant challenge is whether the approach of statecraft theory is helpful in contexts other than Britain. Statecraft was argued by Bulpitt to be necessary because of the adversarial institutional dynamics of Westminster politics. It follows that the approach would appear to have equal utility in other countries that had similar parliamentary-plurality - 'winnertakes-all' constitutional frameworks with strong executives - because the electoral imperatives that drive statecraft remain. Obvious examples would be Australia, Canada and New Zealand, although Lijphart's majoritarian-consociationalist framework (1999) provides one crude way of identifying such polities. This implies, however, that the approach might be of less utility in polities characterized by multiparty coalitions, consensual, inclusive and accommodative decisionmaking, such as the Netherlands, because the Darwinian logics of electoral survival are not the same and elites might behave differently. This might not necessarily be true, however, because competitive elections might be sufficiently important in informing decision-making. Coalition partners are still concerned about the public's perceptions of governing competence and need to manage their party effectively. A more significant reason why the approach might be less useful in these polities is that the approach ceases to offer parsimony. In polities characterized by multiparty politics, where many parties can play a role in government, which court do we study? There might be a need to study the statecraft strategies of all parties. Focusing on the court(s) is still worthwhile because it brings their strategic behaviour into focus as a source of policy change. However, it is a messier exercise. We are less likely to find powerful central actors who can readily break institutional path dependencies.

A second reason, not considered by Bulpitt, for why the statecraft approach works so well in the UK is that it has a top-down political culture. As Marsh et al. (2003: 310) note, there is a tendency in the study of British politics to 'focus on institutions and play down the importance of ideas and culture'. However, according to them, Britain has a distinct politico-administrative culture. This is characterized by a limited liberal conception of representation and a conservative notion of responsibility where 'government knows best', the notion of parliamentary sovereignty 
in which the executive is 'executive is accountable to the voters at periodic free and fair elections and to parliament between elections' and an 'obsession with strong, decisive, necessary action with limited scrutiny' (Marsh et al. 2003: 311, 312). This top-down culture therefore makes the court the logical focus of analysis for policy change because it accepted to be the key actor within the political system. It follows, therefore, that the statecraft approach will be most useful in explaining institutional change in other political systems where a top-down culture accompanies institutional centralization. This might apply not only to other majoritarian democracies, but also to semi-democratic states and electoral autocracies.

\section{A MACRO APPROACH}

A third advantage of using Bulpitt's work to explain policy change is that it provides a macro perspective to understanding institutional change. Theories of policy change are commonly categorized as being either meta- or macro-, meso- or micro-level theories. New institutionalist theories are generally recognized as being meso: 'middle range or bridging level of analysis' (Parsons 1997: 85). As Evans and Davies (1999: 363) note, the 1990s saw an 'upsurge of interest' in meso-level analysis because of the interest in new governance (Rhodes 1996), to the extent that meso-level analysis 'became the crucial analytical tool for multi-level, integrative analysis' (Evans and Davies 1999: 363). The downside of meso-level analysis, however, is that it can make important factors in institutional change exogenous. As noted above, a common criticism of historical institutionalism was that it made too many causal sources of change exogenous to the institutions under study as either 'punctuated equilibrium', 'critical junctures' or 'contingent factors'. They may therefore miss many important sources of change.

One of Bulpitt's core concerns was the importance of macro analysis. In his later work he developed a critique of mainstream British political science as suffering from, amongst other things, the compartmentalization of the study of British politics. Bulpitt explicitly wrote in critique of approaches that only analyse one part of the larger polity. This, he claims, had become the trend in British political science by the mid-1990s. Thus, political parties, voters and the major institutions of government are discussed in separation from each other. He points to how standard textbooks on British politics illustrate this. They are divided into chapters on 'voters, parties, pressure groups, the major institutions of government plus, and these days, a number of policy case studies' (Bulpitt 1995: 511). The end result is either a failure to generate a macro analysis integrating the polity as a whole or an inaccurate picture of the state as the arbitrator of these groups; in short, pluralism. Such analysis - based on a 'bottom-up methodology' creates 
'sociologism' (Bulpitt 1995: 512). His alternative was a macro approach, which he admitted was difficult, since it involved 'some knowledge about a lot of things. Hence, accusations of superficiality are always possible (and plausible' (Bulpitt 1995: 515). But a macro approach would overcome the loss of an overall narrative of traditional methodologies.

Bulpittian macro analysis can also sensitize us to otherwise neglected linkages between layers of the meta-macro-meso-micro nexus that emerge from macro political change. For example, at the micro level, policy continuity can be a result of deliberate non-intervention by the court. Bulpitt noted that the centre would often deliberately not intervene in a policy area to increase its chance of achieving successful statecraft. For example, he saw race relations as a policy area that had huge potential for political conflict in national politics. However, writing in 1986, Bulpitt claimed that '[a]t no point between the late 1940s and the mid-1980s has the race issue occupied a continuous and important place on the national political agenda. Race conflict has had only a sporadic impact on the English polity' (Bulpitt 1986b: 23). This was because the court had sought, and achieved, autonomy or insulation on the issue by seeking to 'off-load prime responsibility for the matter to other people and other agencies' (Bulpitt 1986b: 23). Key to this was the 'peripheralisation of race problems: their injection into local government and local politics as operational issues' (Bulpitt 1986b: 23). This was largely successful and was one of the 'great political "jobs" of the 20th century' (Bulpitt 1986b: 23). Meso- or micro-level analysis might explain change in terms of shared values or networks of policymakers. However, while the empirical findings from his case study of race-relations may be less than perfect, Bulpittian analysis uniquely refocuses the lens on otherwise overlooked strategic actors, even if their involvement is not immediately observable. Institutional drift may therefore occur because of strategic statecraft. The court may thus deliberately depoliticize or try to pass off a function to another actor. Bulpitt's work therefore inspired recent work on the concept of politicization (Buller and Flinders 2005; Flinders and Buller 2006).

Simultaneously, if a court believes that its strategic interests are affected by a policy issue in which it previously has not been a stakeholder, it will seek to intervene. One study which illustrates this is James' (2010) application of the statecraft approach to UK electoral administration. Electoral administration is a policy area traditionally seen as a micro issue in the UK. There have only been a handful of minor changes made to election administration throughout the twentieth century. This was a relatively minor and technocratic issue which was dealt with by officials in the Home Office, representatives from local government and professional associations. 
However, from 1997 to 2007 the New Labour government began to take a political interest in the area because it could solve a strategic problem that it faced. Turnout was in decline in the UK and fewer and fewer of Labour's 'core vote' were sufficiently enthused to vote on polling day. Other solutions such as amending the electoral system to proportional representation were a 'no go' because they would adversely affect the power of the party. In short, by tracing the interests of the elite and by using macro analysis, it is possible to identify how macro-level agents may intervene in policy areas and bring about change.

Strategic intervention and non-intervention is also important at the meta level in international affairs. In the domain of foreign policy, governing competence 'denotes the specific tactics employed to minimise the adverse impact of external forces on domestic politics in ways acceptable to the governing party, and, in the process, make life difficult for opposition groups' (Bulpitt 1988: 195-6). Bulpitt further suggested that a number of 'ploys' can commonly be used to achieve governing competence on foreign policy: foreign policy successes, ${ }^{4}$ rational inactivity, deliberate politicization, the reversal of assignments and Britain's role in concentric circles (Bulpitt 1988: 195-9). Bulpitt advised that non-intervention in a range of foreign affairs was often the wisest approach. Public sector management reforms and the (non)presence of policy networks at the meso level may also owe much to the strategic activity of the court - or the historical legacies and unintended consequences of such activity.

One disadvantage of a macro approach is that it is overkill - we are taking an analytical sledgehammer to crack a nut. We therefore lack the finer detailed analysis which comes with meso-level analysis. However, it is possible to combine the statecraft approach with compatible meso and micro theories. For example, James $(2011,2012)$ argues that the interest of the court in election administration ebbs and flows according to an issue agenda and the nature of the constitutional and party system. Policy triggers are identified which may make the court interested in election administration such as 'administrative failure', declining turnout or the availability of new technology. Micro- or meso-level factors can therefore feed-up to the macro level to bring about change, but they must commonly navigate through the macro level. Other conceptual tools from the academic literature on the policy process, agenda cycle and comparative political parties can therefore be used in accompaniment to examine the problem in hand.

In summary, new institutionalism self-consciously focused on meso-level analysis because of the perceived presence in distinct policy arenas, policy communities and vertical silos in 
government. However, a Bulpittian focus on the strategic activity of the court helps to explain both institutional continuity and change by identifying how this actor allows institutional drift provides critical junctures and therefore sensitizes analysis to new sources of institutional change.

\section{CONCLUSION}

This article has sought to establish where statecraft theory 'fits' in the search to explain institutional change and evaluate its added value. As C.S. Lewis ([1955] 2008: 136) said: 'What you see and what you hear depends a good deal on where you are standing'; and indeed, what you are looking at. Complete relativism is unhelpful for political analysis. It is certainly the case, however, that the sources of institutional change that analysts see and hear depends a good deal on which actors they focus their study on. The statecraft approach focuses analysis around one critical actor. This means that the approach is open to the criticism of being reductionist because it misses other sites of conflict which might influence the institutional change. It may therefore be more likely to miss more important venues for change in contexts where the court is less important. Yet in many states the centre is a central actor which does have the power to break and shape path-dependencies. Statecraft theory allows us to identify, when, where and why it is or is not willing or able to try to do this and sensitizes analysis to some under-explored factors of institutional change. Firstly, the approach offers a nuanced critical realist model of change (and continuity) based in structure and agency rather than just path dependencies. It provides an agent-led theory of change within historical institutionalism. Most historical institutionalists fail to specific the key critical actor of focus and this inhibits agency. Secondly, it brings back into focus the importance of electoral politics which were not always clear in the work of the neo-statists. Thirdly, it provides a macro approach which can thereby identify unnoticed sources of stability and change.

A new generation of scholarship may therefore find fresh insights from using neo-statecraft theory to understand continuity and change in Britain and elsewhere. Although the approach might be better suited to states with strong executives, this covers a huge area of the world. The late twentieth century witnessed a huge rise in the number of states with leaders that needed to win elections to maintain power, even if these elections were imperfect compared to democratic theory or international standards, and they governed through partly authoritarian methods (Levitsky and Way 2002; Norris 2013). It has been remarked elsewhere (Savage and Williams 
2008) that the tradition of political elite theory, which included the great work from Robert Michels, James Burnham, Floyd Hunter and C. Wright Mills, spawned few successors. However, here is an elitist approach which can be adopted by comparativists.

Grounding neo-statecraft within historical institutionalism also opens up further opportunities. It follows that future work using statecraft might benefit from systematically exploring and using the newer concepts from historical institutionalism and comparative historical analysis such as drift, layering and reactive sequences. These are themselves relatively underexplored. It certainly follows that using a statecraft approach implies developing a historical approach to understand the temporal development of governing challenges and how they are confronted.

The reworking of 'great texts' is invariably controversial. Bulpitt's work has already been claimed by interpretivists, as noted above. There might be objections to the use of realism and historical institutionalism. Although the argument here is clearly that they are well suited, such pluralism is good. By explicitly developing a neo-statecraft, this article aims to delineate a clear pathway for a new, largely unrecognized, approach to institutional change and governance which does not make the emergence of other pathways impossible.

\section{ACKNOWLEDGEMENTS}

Earlier versions of this paper were presented at the 2011 Public Administration Committee Conference at the University of Birmingham, where the paper was the winner of a Sage 'best paper' prize and the 2013 Political Studies Association Conference at Cardiff City Hall. I am especially grateful to participants at those conferences, Jonathan Bradbury, Rod Rhodes and the reviewers from Government \& Opposition for their constructive feedback. The author remains responsible for any errors.

\section{NOTE}

\footnotetext{
${ }^{1}$ This fits with the definition used by Steeck and Thelan (2005: 10-16).

${ }^{2}$ Adcock et al. (2007: 288) claim that historical institutionalism is 'guided by concerns and techniques that are so diverse that they may border on incompatibility', however it is possible to discern some core tenants. It is commonly thought to have its intellectual antecedents in the work of the neo-statists such as Theda Skocpol et al. (1985), who sought to Bring the State Back In and the study of American political development (Bridges 1984; Showronek 1982), which both developed an interest in qualitative macro-
} 
historical, small-n studies. Today, historical institutionalism shares much with what is also referred to as comparative historical analysis.

${ }^{3}$ Also see Mahoney and Thelan (2010).

${ }^{4}$ Bulpitt called these 'conflict resolutions' but suggested that 'this is an up-market label for what in plainer English would be called foreign policy successes' (Bulpitt 1988: 196). For the sake of clarity, it seems easier to just accept the 'bog-standard' term.

\section{REFERENCES}

Adcock, R., Bevir, M., and Stimson, S. C. (2007). Historicizing New Institutionalism. In R. Adcock, M. Bevir and S. C. Stimson (Eds.), Modern political science: Anglo-American exchanges since 1880 (pp. 259-289). Princeton, NJ: Oxford University Press.

Baumgartner, F.R., and Jones, B. D. (1991). Agenda dynamics and policy subsystems. Journal of Politics, 53, 1044-1074.

Bertelli, A. M., and John, P. (2013). Public Policy Investment: Risk and Return in British Politics. British Journal of Political Science, 43(4), 741-773., 1-33.

Bevir, M. (2010). Interpreting Territory and Power. Government and Opposition, 45(3), 436-456.

Blais, A., and Nadeau, R. (1992). The electoral budget cycle. Public Choice, 74(4), 389-403.

Bradbury, J. (2006). Territory and Power Revisited: Theorising Territorial Politics in the United Kingdom after Devolution. Political Studies, 54, 559-582.

Bradbury, J. (2010). Interpreting political development and bringing the government of the state back in: Jim Bulpitt's Territory and Power and the case of the United Kingdom Government and Opposition, 45(3), 318-344.

Brenner, N. (2004). Urban governance and the production of new state spaces in western Europe, 1960-200. Review of International Political Economy, 11(3), 447-4488.

Bridges, A. B. (1984). A City in the Republic, Antebellum New York and Origins of Machine Politics. New York: Cambridge University Press.

Buller, J. (1999). A Critical Appraisal of the Statecraft Interpretation. Public Administration, 77(4), 691-712.

Buller, J. (2000). National Statecraft and European Integration. London: Cassell.

Buller, J., and Flinders, M. (2005). The Domestic Origins of Depoliticisation in the Area of British Economic Policy British Journal of Politcs and International Relations, 7(4), 526.

Buller, J., and James, T. S. (2012). Statecraft and the Assessment of National Political Leaders: The Case of New Labour and Tony Blair. The British Journal of Politics and International Relations, 14(4), 534-555.

Buller, J., and James, T. S. (2014). Assessing Prime Ministerial Performance:

Structural Contexts, Statecraft and the Case of Gordon Brown, paper presented at the Political Studies Association Political Leadership Annual Workshop, University of East Anglia, 17th January 2014.

Bulpitt, J. (1967). Party Politics in English Local Government Longman.

Bulpitt, J. (1986a). The discipline of the New Democracy: Mrs. Thatcher's Domestic Statecraft. Political Studies, 34(1), 19-39.

Bulpitt, J. (1986b). Continuity, autonomy and peripherialisation: the anatomy of the centre's race statecraft in England. In Z. Layton-Henry and P. Rich (Eds.), Race, government and politics in Britain (pp. 17-44). Basingstoke: Macmillan.

Bulpitt, J. (1988). Rational politicians and Conservative statecraft in the open polity. In P.Bryd (Ed.), British Foreign Policy under Thatcher (pp. 180-205). Deddington: Philip Allan. 
Bulpitt, J. (1989). Walking back to Happiness? Conservative Party Governments and elected local authorities in the 1980s. In C. Crouch and D. Marquand (Eds.), The New Centralism:

Britain Out of Step in Europe? (pp. 56-73). Oxford: Blackwell.

Bulpitt, J. (1995). 'Historical Politics: macro, in-time, governing regime analysis'. In J.Lovenduski and J.Stanyer (Eds.), Contemporary Political Studies Vol II (pp. 510-520). Belfast: Political Studies Association.

Bulpitt, J. (1996). Historical Politics: Leaders, Statecraft and Regime in Britain at the Accession of Elizabeth II. In I. Hampster-Monk and J. Stayner (Eds.), Contemporary Political Studies, vol. 2 (pp. 1093-1106). Oxford: Blackwell.

Bulpitt, J. ([1983]2008). Territory and Power in the United Kingdom. Colchester, Essex: ECPR.

Bulpitt, J., and Burnham, P. (1999). Operation Robot and the British Political Economy in the Early 1950s: The Politics of Market Strategies. Contemporary British History, 13(1), 1-31.

Burnham, P. (2001). New Labour and the politics of depoliticisation. British Journal of Politcs and International Relations, 3(2), 127-129.

Capoccia, G., and Keleman, R. D. (2007). The Study of Critical Junctures: Theory, Narrative, and Counterfactuals in Historical Institutionalism. World Politics, 59, 341-369.

Castells, M. (1996). The Rise of the Network Society: The Information Age, Economy, Society and Culture. Oxford: Blackwell.

Cowling, M. (1967). 1867 Disraeli, Gladstone and Revolution. Cambridge: Cambridge University Press.

Cowling, M. (1971). The Impact of Labour 1920-1924. Cambridge: Cambridge University Press.

Cowling, M. (1980). Religion and public doctrine in modern England. New York: Cambridge University Press.

Craig, D. M. (2010). 'High Politics' and the 'New Political History'. The Historical Journal, 53(02), 453-475.

Davies, J. S. (2009). The limits of joined-up government: towards a political analysis. Public Administration, 87(1), 80-96.

Davies, J. S. (2011). The Limits of Post-traditional Public Administration: Towards a Gramscian Perspective. Critical Policy Studies, 5(1), 47-62.

Evans, M. (2006). Elitism. In C. Hay, M. Lister and D. Marsh (Eds.), The State: Theories and Issues (pp. 39-58). Basingstoke: Macmillan.

Evans, M., and Davies, J. (1999). Understanding Policy Transfer: A Multi-Level, Multi-Disciplinary Perspective. Public Administration, 77(2), 361-385.

Evans, P. B., Rueschemeyer, D., and Skocpol, T. (Eds.). (1985). Bringing the State Back In. Cambridge: Cambridge University Press.

Flinders, M., and Buller, J. (2006). Depoliticisation: Principles, Tactics and Tools. British Politics, 1(3), 293-318.

Greenaway, J., Salter, B., and Hart, S. (2007). How Policy Networks Can Damage Democratic Health: A Case Study in the Government of Governance. Public Administration, 85(3), 717-738.

Hall, P., and Taylor, R. C. R. (1996). Political Science and the Three New Institutionalisms. Political Studies, 44(4), 936-957.

Hall, P. A. (2010). Historical Institutionalism in Rationalist Sociological Perspective. In J. Mahoney and K. Thelan (Eds.), Explaining Institutional Change: Ambiguity, Agency and Power (pp. 204-224). New York: Cambridge University Press.

Hay, C., and Wincott, D. (1998). Structure, Agency and Historical Institutionalism. Politcal Studies, XLVI, 951-957.

Hirst, P., and Thompson, G. (1999). Globalisation in Question. Cambridge: Polity Press. 
Hopkin, J., and Paolucci, C. (1999). The business firm model of party organisation: cases from Spain and Italy. European Journal of Political Research, 35(3), 307-339.

James, T. S. (2010). Electoral modernisation or elite statecraft? Electoral administration in the U.K. 1997-2007. British Politics, 5(2), 179-201.

James, T. S. (2011). Only in America? Executive partisan interest and the politics of election administration in Ireland, the UK and USA. Contemporary Politics, 17(3), 219-240.

James, T. S. (2012). Elite Statecraft and Election Administration: Bending the Rules of the Game. Basingstoke: Palgrave Macmillan.

Katz, R. S., and Mair, P. (2009). The Cartel Party Thesis: A Restatement. Perspectives on Politics, 7(04), 753-766.

Katznelson, I. (2003). Periodization and Preferences: Reflections on Purposive Action in Comparative Historical Social Science. In J. Mahoney and D. Rueschemeyer (Eds.), Comparative Historical Analysis in the Social Science New York: Cambridge University Press.

Krasner, S. (1984). Approaches to the State: Alternative Conceptions and Historical Dynamics. Comparative Politics, 16(2), 223-246.

Krasner, S. (1988). Sovereignty: a institutionalists perspective. Comparative Politics, 21, 66-94.

Lewis C.S. ([1955]2000), The Magician'S Nephew. New York: Harper Collins.

Levitsky, S., and Way, L. A. (2002). The Rise of Competitive Authoritarianism. Journal of Democracy, 13(2), 51-65.

Lijphart, A. (1999). Patterns of Democracy. London: Yale University Press.

Lodge, M., and Wegrich, K. (2012). Public administration and executive politics: perennial questions in changing contexts. Public Policy and Administration, 27(3), 212-229.

Lowndes, V. (1996). Varieties of New Institutionalism: A critical appraisal. Public Administration, 74(Summer 1996), 181-197.

Lowndes, V., and Roberts, M. (2013). Why Institutions Matter. Basingstoke: Palgrave.

Mahoney, J. (2000). Path dependence in historical sociology. Theory and Society, 29(4), 507-548.

Mahoney, J., and Rueschemeyer, D. (2003). Comparative historical analysis in the social sciences. New York: Cambridge University Press.

Mahoney, J., and Thelan, K. (2010). A Theory of Gradual Institutional Change. In J. Mahoney and K. Thelan (Eds.), Explaining Institutional Change: Abiguity, Agency and Power (pp. 1-37). New York: Cambrudge University Press.

March, J. G., and Olsen, J. P. (1984). The new institutionalism: organisational factors in political life. American Political Science Review, 78, 734-749.

Marsh, D. (1995). Explaining 'Thatcherite'Policies: Beyond Uni-dimensional Explanation Political Studies, 43(3), 595-613.

Marsh, D. (2008). Understanding British Government: Analysing Competing Models. The British Journal of Politics and International Relations, 10(2), 251-268.

Marsh, D. (2012). British politics: A view from afar. British Politics, 7(1), 43-54.

Marsh, D., Smith, M. J., and Richards, D. (2003). Unequal Plurality: Towards an Asymmetric Power Model of British Politics. Government and Opposition, 38(3), 306-332.

McKenna, D. (2012). Councillor Attitudes towards Participatory Initiatives: A Bulpittian Perspective. Public Money and Management, 32(2), 103-110.

Mendez, C. (2012). Clouds, clocks and policy dynamics: a path-(inter)dependent analysis of EU cohesion policy. Policy and Politics, 40(2), 153-170.

Norris, P. (2013). The new research agenda studying electoral integrity. Electoral Studies.

Ohmae, K. (1990). The Borderless World. London: Collins. 
Parsons, W. (1997). Public Policy: An Introduction to the Theory and Practice of Policy Analysis. London: Edward Elgar.

Peters, G. (1999). Institutional Theory in Political Science: The 'New Institutionalism' London: Pinter.

Peters, G., Pierre, J., and King, D. S. (2005). The politics of path dependency: Political conflict in historical institutionalism Journal of Politics, 67(4), 1275-1300.

Rhodes, R. A. W. (1988). Beyond Westminister and Whitehall. London: Unwin Hyman.

Rhodes, R. A. W. (1996). The New Governance: Governing Without Governance. Political Studies, 44, 652-667.

Rhodes, R. A. W. (1997). Understanding Governance. Buckingham: Open University Press.

Rhodes, R. A. W., and Tiernan, A. (2013). From Core Executives to Court Politics: from a bucket of rice to a bowl of jelly, Political Studies Annual Conference. Cardiff.

Sanders, E. (2006). Historical Institutionalism. In R. A. W. Rhodes, S. A. Binder and B. A. Rockman (Eds.), The Oxford Handbook of Political Institutions. Oxford Oxford University Press.

Savage, M., and Williams, K. (2008). Elites: remembered in capitalism and forgotton by social sciences. The Sociological Review, 56, 1-24.

Savigny, H. (2007). Ontology and Epistemology in Political Marketing Keeping It Real? . Journal of Political Marketing, 6(2 and 3), 33-47.

Savitch, H. V., and Osgood, J. J. L. (2010). Bulpitt in America: Presidential Approaches, Territorial Politics and the Field of Urban Policy. Government and Opposition, 45(3), 406-435.

Sayer, A. (1992). Method in Social Sciences (Second Edition ed.). Sussex: Hutchinson University Library.

Sayer, A. (2000). Realism and Social Science. London: Sage.

Showronek, S. (1982). Building a New American State: The Expansion of National Administrative Capacities 1877-1920. Cambridge: Cambridge University Press.

Stacey, J. (2013). The Statecraft approach: A case study of Nicolas Sarkozy. French Politics, 11(3), 284-306.

Steinmo, S., Thelen, K., and Longstreth, F. (1992). Structuring Politics: Historical Institutionalism in Comparative Analysis. Cambridge: Cambridge University Press.

Strange, S. (1996). The retreat of the state : the diffusion of power in the world economy. Cambridge University Press: Cambridge.

Streeck, W., and Thelan, K. (2005). Introduction: Institutional Change in Advanced Political Economies. In W. Streeck and K. Thelan (Eds.), Beyond Continuity (pp. 1-39). Oxford: Oxford University Press.

Weiss, L. (1998). The myth of the powerless state : governing the economy in a global era. Polity Press: Cambridge, UK. 